Historic, Archive Document

Do not assume content reflects current scientific knowledge, policies, or practices. 



\section{ONION AND OKRA SEED, ETC. At Surplus Prices to the Seed Trade}

Offered if unsold on receipt of order, bags extra, F. O. B. Philadelphia, Pa., or Moorestown, N. J. Terms 60 days net. 2 per cent. ten days.

\section{ONION}

140 lb. Southport Yellow Globe

90 lb. Southport Red Globe

(1) $45 c$

15 lb. Australian Brown

$50 \mathrm{c}$

20 lb. Red Bermuda

$40 c$

70 lb. White Bermuda

$50 \mathrm{c}$

$50 \mathrm{c}$

\section{OKRA}

35 lb. Dwarf Prolific

(a) $10 \mathrm{c}$

\section{ASPARAGUS}

300 lb. Palmetto

(a) $10 \mathrm{c}$

Orders received by 12 o'clock noon will be forwarded same day.

STOKES SEED FARMS COMPANY MOORESTOWN, NEW JERSEY 


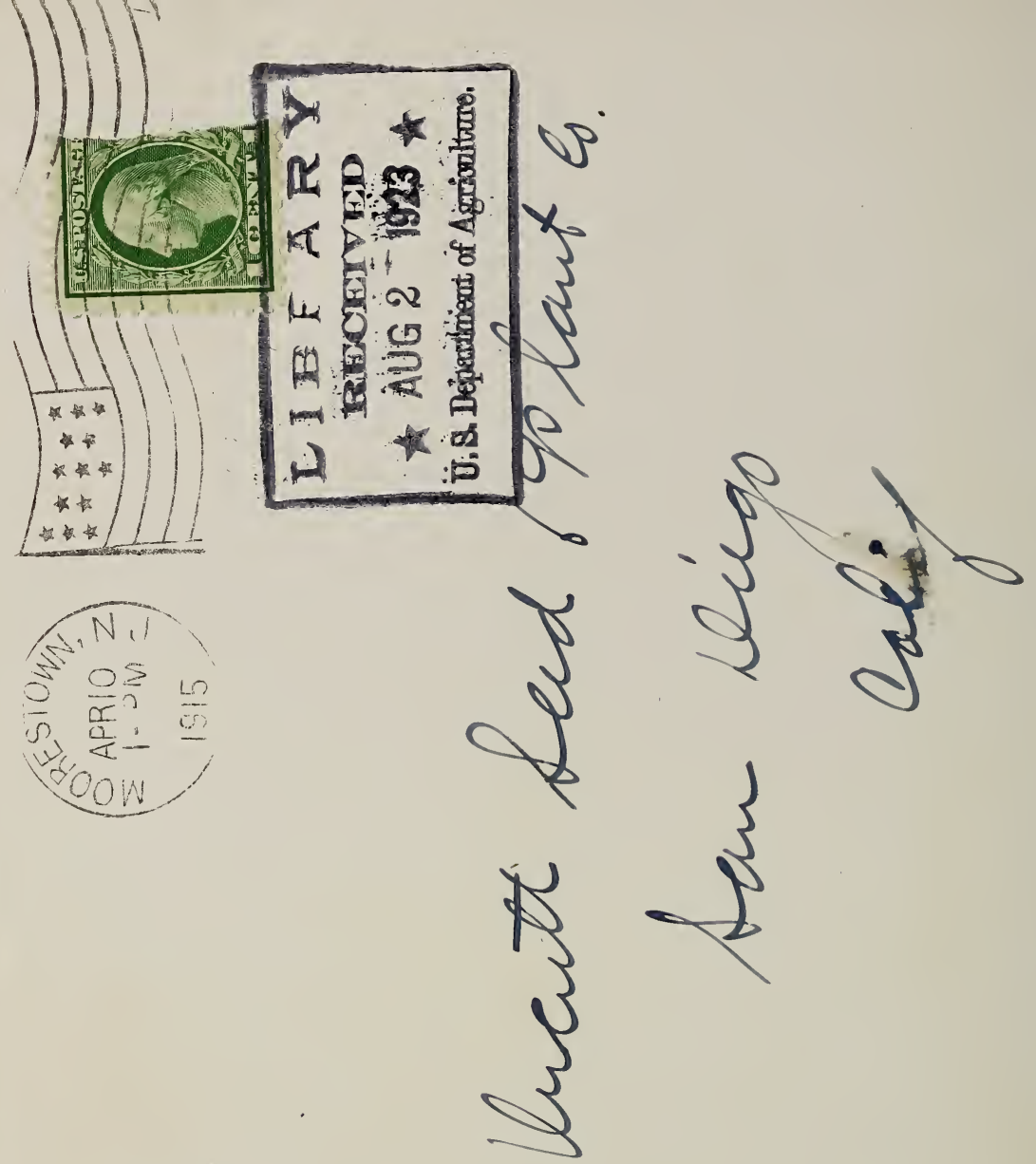

